\title{
Clusterisasi Kerusakan Gempa Bumi di Pulau Jawa Menggunakan SOM
}

\author{
Earthquake Damage Clustering in Java Island Using SOM \\ Hartatik*1, Arifa Satria Dwi Cahya $^{2}$ \\ ${ }^{*}$ Program Studi Manajemen Informatika, Fakultas Ilmu Komputer, Universitas AMIKOM Yogyakarta \\ ${ }^{2}$ Program Studi Informatika, Fakultas Ilmu Komputer, Universitas AMIKOM Yogyakarta \\ e-mail: "1hartatik@ amikom.ac.id ${ }^{2}$ arifa@ student.amikom.ac.id
}

\begin{abstract}
Abstrak
Indonesia sebagai negara yang diapit oleh 3 lempeng membuat negara ini cukup sering diguncang oleh Gempa. Pada tahun 2018, BMKG mencatat ada sebanyak 23 gempa yang masuk dalam kategori merusak. Setengahnya berada di Pulau Jawa. Pemetaan daerah rawan gempa dan jenis kerusakan yang terjadi perlu dilakukan untuk meminimalisir terjadinya kerusakan dan mitigasi bencana. SOM (Self-Organizing Map) merupakan metode clustering yang pernah digunakan untuk melakukan pengelompokan daerah gempa dan kerusakan yang terjadi. Metode SOM banyak digunakan untuk melakukan pengelompokan karena cenderung stabil dimana nilai centroid tidak berubah di setiap pengujian. Dataset yang digunakan berjumlah 1000 data diambil langsung dari web BMKG pada rentang waktu Januari 2019 sampai dengan Juni 2019. Akurasi dihitung menggunakan metode K-Fold Validation dengan membagi data set ke dalam 5-fold dan 10-fold data testing yang masing-masing berisi 200 dan 100 data. Hasil pengujian menunjukkan nilai akurasi algoritma SOM yang tertinggi adalah dengan alpha 0.2 untuk 5-Fold yaitu 96.20\% dan 0.3 untuk 10-Fold yaitu 95.6\% pada minimal iterasi 20 dan yang terendah adalah alpha 0.1 yaitu 85.90\% mulai dari iterasi 10.
\end{abstract}

Kata kunci-cluster, Gempa Bumi, SOM (Self Organizing Map)

\begin{abstract}
Indonesia as a country that is flanked by 3 plates makes this country rocked quite often by earthquakes. In 2018, BMKG recorded 23 earthquakes that were categorized as damaging. Half of them are on the island of Java. Mapping of earthquake-prone areas and the types of damage that occurs needs to be done to minimize damage and mitigate disasters. SOM (Self-Organizing Map) is a clustering method that has been used to group earthquake areas and the damage that occurred. The SOM method is widely used for grouping because it tends to be stable where the centroid value does not change in each test. The data set used is 1000 data taken directly from the BMKG website from January 2019 to June 2019. Accuracy is calculated using the K-Fold Validation method by dividing the data set into 5-fold and 10-fold testing data, each of which contains 200. and 100 data. The test results show that the highest accuracy value of the SOM algorithm is alpha 0.2 for 5-Fold, namely $96.20 \%$ and 0.3 for 10-Fold, which is $95.6 \%$ at a minimum of 20 iterations and the lowest is alpha 0.1, namely $85.90 \%$ starting from iteration 10.

Keywords-Cluster, Earthquake, SOM (Self Organizing Map)
\end{abstract}

\section{PENDAHULUAN}

Indonesia merupakan negara yang memiliki tingkat kerawanan gempa bumi cukup tinggi. Hal tersebut karena posisi Indonesia terletak pada wilayah pertemuan tiga buah lempeng besar berukuran benua yang secara terus menerus bergerak[1]. Ketiga lempeng aktif tersebut adalah Hindia-Australia, Pasifik dan Eurasia. Selain itu Indonesia juga termasuk dalam wilayah yang memiliki sistem seismotonik yang tergolong rumit dengan frekuensi kejadian gempa bumi cukup tinggi. Hal ini menjadikan Indonesia termasuk negara yang memiliki ancaman bencana gempa bumi cukup tinggi di bandingkan dengan negara lainnya.

Informasi Artikel:

Submitted: Mei 2020, Accepted: Agustus 2020, Published: November 2020

ISSN: 2685-4902 (media online), Website: http://jurnal.umus.ac.id/index.php/intech 
Pusat gempa adalah suatu titik sumber gempa yang terdapat pada kedalaman tertentu yang dapat menjadi titik terparah suatu gempa[2]. Gempa bumi terkuat yang pernah terjadi adalah gempa yang berpusat pada Samudra Hindia yang memicu tsunami Aceh Tahun 2004 dengan kekuatan 9.3 skala richter (SR) sehingga menimbulkan 131.028 korban jiwa dan lebih dari 37.000 orang dinyatakan hilang[3]. Menurut data dari Badan Nasional Penanggulangan Bencana (BNPB) dalam 5 tahun terakhir telah terjadi 110 bencana gempa bumi yang terjadi di Indonesia. Dari 110 gempa bumi tersebut, sebanyak 157 orang meninggal dan hilang, 4.375 orang luka-luka, 192.488 orang mengungsi, 13.670 rumah rusak berat, 8.978 rumah rusak sedang, 23.401 rumah rusak ringan, 451 fasilitas kesehatan rusak, 648 fasilitas peribadatan rusak, dan 1.832 fasilitas pendidikan rusak. Dengan memperhatikan beberapa tingkat kerawanan yang ada, maka data-data mengenai gempa yang pernah terjadi di wilayah Indonesia perlu dianalisa sehingga diketahui wilayah mana sajakah yang sering terjadi gempa. Berdasarkan hal tersebut, maka penelitian ini bertujuan untuk mengelompokkan tingkat kerusakan dan tingkat kekuatan gempa yang berada di Pulau Jawa melalui pendekatan SOM. Metode SOM dipilih karena metode ini mampu melakukan pengelompokan yang lebih cenderung stabil karena sedikitnya percabangan yang dihasilkan[4] dimana nilai centroid tidak berubah di setiap pengujian dan juga penentuan cluster dilihat berdasarkan jarak minimum antara data input ke neuron[5]. Akurasi pengujian akan dilakukan melalui K-Fold Cross Validation karena mampu meminimalisir bias pada data yang didapatkan sehingga akurasi terhadap prediksi model didapatkan secara maksimal melalui pengujian sebanyak $k$ kali[6].

Sebelumnya penelitian mengenai clustering gempa dengan metode SOM telah dilakukan oleh beberapa peneliti terdahulu, salah satunya adalah pengelompokkan terhadap 26 Provinsi yang ada di Indonesia selama kurun waktu 2000 - 2016 menjadi empat cluster melalui pendekatan 14 variabel dampak gempa [7]. Selain itu, pengelompokkan gempa bumi yang terjadi di Indonesia juga pernah dilakukan dengan metode CLARA (Clustering Large Application) dimana berdasarkan 7059 data dari United States Geological Survey (USGS) didapatkan bahwa pengelompokkan gempa berdasarkan kedalaman dan besarnya magnitude menghasilkan tiga kelompok yaitu: kelompok gempa dengan pusat gempa di Laut Sawu, kelompok gempa dengan pusat gempa di Samudra Hindia, dan kelompok gempa dengan pusat gempa di Desa Menetwati [8]. Selain menggunakan SOM dan CLARA, pengelompokkan gempa juga pernah dilakukan melalui algoritma K-Means, dimana berdasarkan hasil penelitiannya menunjukkan beberapa dampak gempa besar yang terjadi di Indonesia adalah kerusakan lahan, jalan dan rumah rusak ringan[9]. Pengelompokkan terhadap beberapa wilayah yang rawan bencana dan tidak rawan bencana juga pernah dilakukan terhadap seluruh Provinsi yang ada di Indonesia, dimana Provinsi Jawa Timur, Jawa Barat dan Jawa Tengah merupakan tiga propinsi yang masuk dalam kategori rawan bencana alam, khususnya gempa bumi [10]. Selain untuk gempa, metode SOM juga pernah digunakan untuk pengelompokkan mutu sekolah melalui evaluasi diri sekolah yang dilakukan di Maluku Kabupaten Morotai, berdasarkan hasil perhitungannya didapatkan bahwa nilai learning rate yang dihasilkan adalah 0,3 dengan MSE $67 \times 10^{-8}[11]$

\section{METODE PENELITIAN}

\section{Data Mining dan Clustering}

Data Mining adalah proses yang menggunakan teknik statistik, matematika, kecerdasan buatan, machine learning untuk mengekstrasi dan mengidentifikasi informasi yang bermanfaat dan pengetahuan yang terkait dari berbagai database besar [12]. Teknik pembelajaran dalam data mining terbagi menjadi tiga kelompok utama yaitu supervised, unsupervised, dan reinforcement Learning [13]. Pengelompokan suatu data dengan menggunakan kedekatan dari data set[14] seperti yang akan digunakan pada penelitian ini masuk ke dalam teknik unsupervised. Beberapa metode yang dapat digunakan dalam unsupervised learning antara lain [13]: 

a. K-Means
b. Hierarchical Clustering
c. DBSCAN
d. Fuzzy C-Means
e. Self-Organizing Map

\section{Tahapan Penelitian}

Pada penelitian ini akan dilakukan pengelompokkan data gempa bumi dengan metode clustering menggunakan algoritma self organizing map sehingga diperoleh pengelompokkan wilayah mana saja di pulau Jawa yang sering terjadi gempa sehingga proses mitigasi dapat dilakukan dengan lebih optimal. Berdasarkan hal tersebut maka langkah penelitian akan dilakukan dengan tahapan seperti pada Gambar 1. Dataset yang digunakan pada penelitian berjumlah 1000 data kegempaan yang diambil dari web BMKG dalam rentang waktu 6 bulan. Selanjutnya dilakukan inisialisasi nilai learning rate $(\alpha)$, nilai bobot $\left(\mathrm{W}_{\mathrm{ij}}\right)$, dan jumlah iterasi. Nilai bobot awal diambil secara acak dari nilai dataset. Setiap nilai output $\mathrm{j}$ akan dihitung nilai jarak terdekat $\mathrm{D}\left(\mathrm{X}_{\mathrm{i}}, \mathrm{W}_{\mathrm{ij}}\right)$ antara nilai node input $X_{i}$ dengan nilai bobotnya $W_{i j}$ menggunakan persamaan (1)

$$
D\left(x_{i}, w_{i j}\right)=\sqrt{\sum_{i=1}^{n}\left(x_{i}, w_{i j}\right)^{2}}
$$

Cari indeks dari sejumlah neuron, yaitu $\mathrm{D}\left(\mathrm{X}_{\mathrm{i}}, \mathrm{W}_{\mathrm{ij}}\right)$, yang mempunyai nilai terkecil. Untuk neuron $\mathrm{j}$ dan semua neuron yang menjadi tetangga $\mathrm{j}$ (yang sudah didefinisikan) dalam radius $\mathrm{r}$ dilakukan pembaruan bobot menggunakan rumus :

$$
w_{i j}(\text { baru })=w_{i j}(\text { lama })+\alpha\left(x_{i}-w_{i j}(\text { lama })\right)
$$

Perbaharui juga nilai learning rate $(\alpha)$ dengan rumus

$$
\alpha(t)=\alpha_{i}\left(1-\frac{t}{t_{\max }}\right)
$$

$\alpha_{\mathrm{t}}$ adalah nilai laju pembelajaran dan $\mathrm{t}_{\max }$ adalah jumlah dari iterasi maksimum. Model akan didapatkan ketika jumlah iterasi telah sesuai.

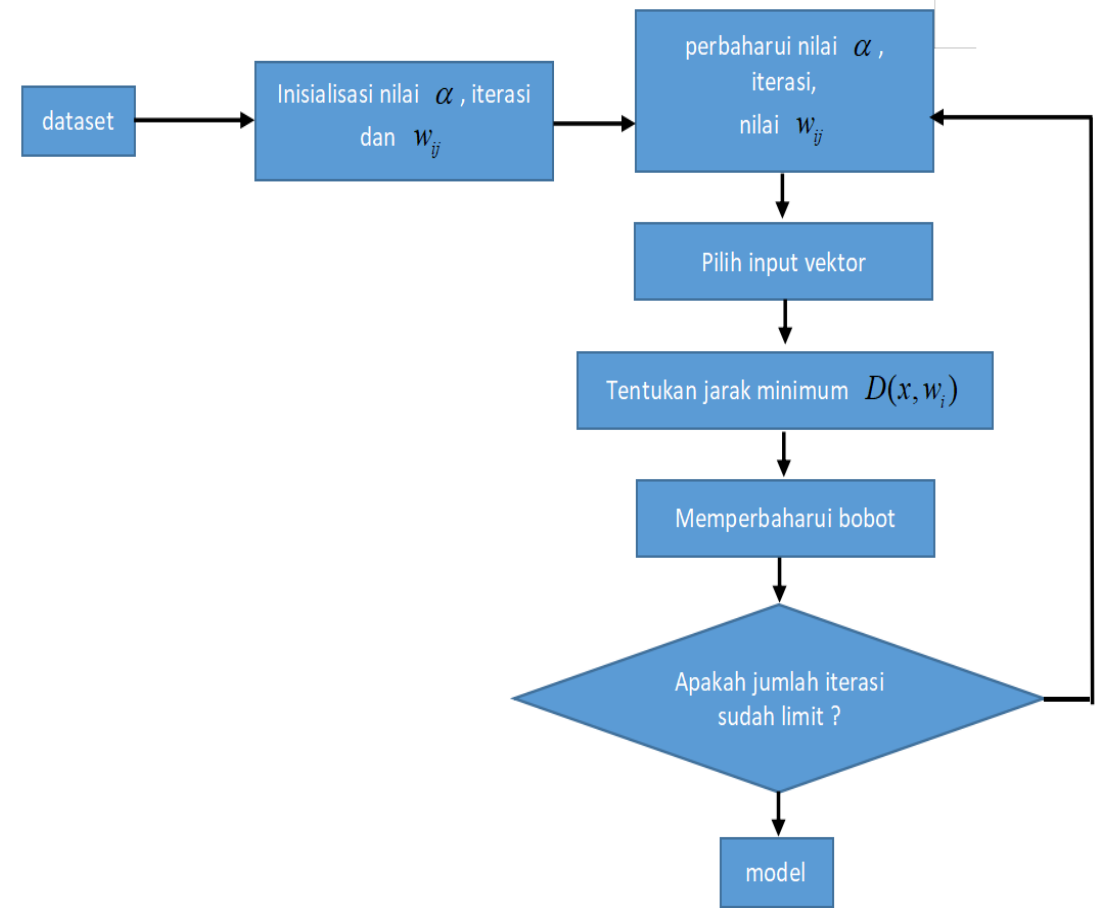

Gambar 1. Tahapan penelitian 


\section{K-Fold Cross Validation}

K-Fold Cross Validation merupakan salah satu metode untuk mengetahui rata-rata keberhasilan suatu sistem melalui perulangan acak atribut masukan, sehingga didapatkan beberapa atribut input yang acak [15][16].

Selain itu pengujian ini juga akan bertujuan untuk mengetahui perbandingan diantara data training dengan data testing[17]. Adapun persamaan jumlah data pada subset terdapat pada persamaan (4)[16]

$$
b=\frac{n}{K_{i}}
$$

Dimana:

$$
\begin{array}{ll}
\mathrm{b} & =\text { banyak data di dalam satu subset } \\
\mathrm{n} & =\text { banyak data yang digunakan } \\
\mathrm{K}_{\mathrm{i}} & =\text { nilai } \text { k-fold cross validation }
\end{array}
$$

Penelitian ini akan menggunakan 2 kali pengujuan yaitu menggunakan 5-fold dan 10-fold, dimana performance akan diuji berdasarkan data uji melalui klasifikasi benar dari data tersebut. Pada 5-fold cross validation, akan dilakukan pengujian sebanyak lima kali dengan empat data training dan satu data testing namun penempatan terhadap masing-masing data training dan data testing tersebut akan berbeda urutan datanya. Rangkuman mengenai gambaran pengujian secara 5-fold cross validation terdapat pada Gambar 2.

\begin{tabular}{lccccc}
\hline Percobaan 1 & Test & Train & Train & Train & Train \\
\hline Percobaan 2 & Train & Test & Train & Train & Train \\
\hline Percobaan 3 & Train & Train & Test & Train & Train \\
\hline Percobaan 4 & Train & Train & Train & Test & Train \\
\hline Percobaan 5 & Train & Train & Train & Train & Test \\
\hline
\end{tabular}

Gambar 2. 5-fold cross validation

Sedangkan untuk pengujian secara 10-fold cross validation jumlah pengujian akan dilakukan sebanyak sepuluh kali pengujian dengan sembilan data training dan satu data testing pada masing-masing pengujian. Rangkuman mengenai gambaran pengujian pengujian secara 10-fold cross validation terdapat pada Gambar 3.

\begin{tabular}{lllllllllll}
\hline Percobaan 1 & Test & Train & Train & Train & Train & Train & Train & Train & Train & Train \\
\hline Percobaan 2 & Train & Test & Train & Train & Train & Train & Train & Train & Train & Train \\
\hline Percobaan 3 & Train & Train & Test & Train & Train & Train & Train & Train & Train & Train \\
\hline Percobaan 4 & Train & Train & Train & Test & Train & Train & Train & Train & Train & Train \\
\hline Percobaan 5 & Train & Train & Train & Train & Test & Train & Train & Train & Train & Train \\
\hline Percobaan 6 & Train & Train & Train & Train & Train & Test & Train & Train & Train & Train \\
\hline Percobaan 7 & Train & Train & Train & Train & Train & Train & Test & Train & Train & Train \\
\hline Percobaan 8 & Train & Train & Train & Train & Train & Train & Train & Test & Train & Train \\
\hline Percobaan 9 & Train & Train & Train & Train & Train & Train & Train & Train & Test & Train \\
\hline Percobaan 10 & Train & Train & Train & Train & Train & Train & Train & Train & Train & Test \\
\hline
\end{tabular}

Gambar 3. 10-fold cross validation 


\section{HASIL DAN PEMBAHASAN}

Pada bab ini akan dibahas mengenai implementasi algoritma SOM dalam mengelompokkan 1000 data kegempaan dengan 2 variabel, yaitu depth dan Magnitude. Inisialisasi awal untuk algoritma ini adalah:
a. Jumlah iterasi $: 50$
b. Jumlah cluster : 3
c. Alpha : :0,2
d. Perubahan alpha $: 0,5$
e. Bobot cluster ke-1 : $115 ; 6,5$
f. Bobot cluster ke-2 : $37 ; 5,4$
g. Bobot cluster ke-3 : $10 ; 3,9$

Gambar 4 merupakan rangkuman mengenai dataset yang akan diolah, dimana data tersebut akan di export melalui excel yang kemudian akan dibaca oleh sistem. Sedangkan nilai bobot untuk cluster 1/2/3 akan diisikan langsung oleh system setelah system membaca jumlah iterasi, nilai alpha, dan perubahan alpha yang diinputkan.

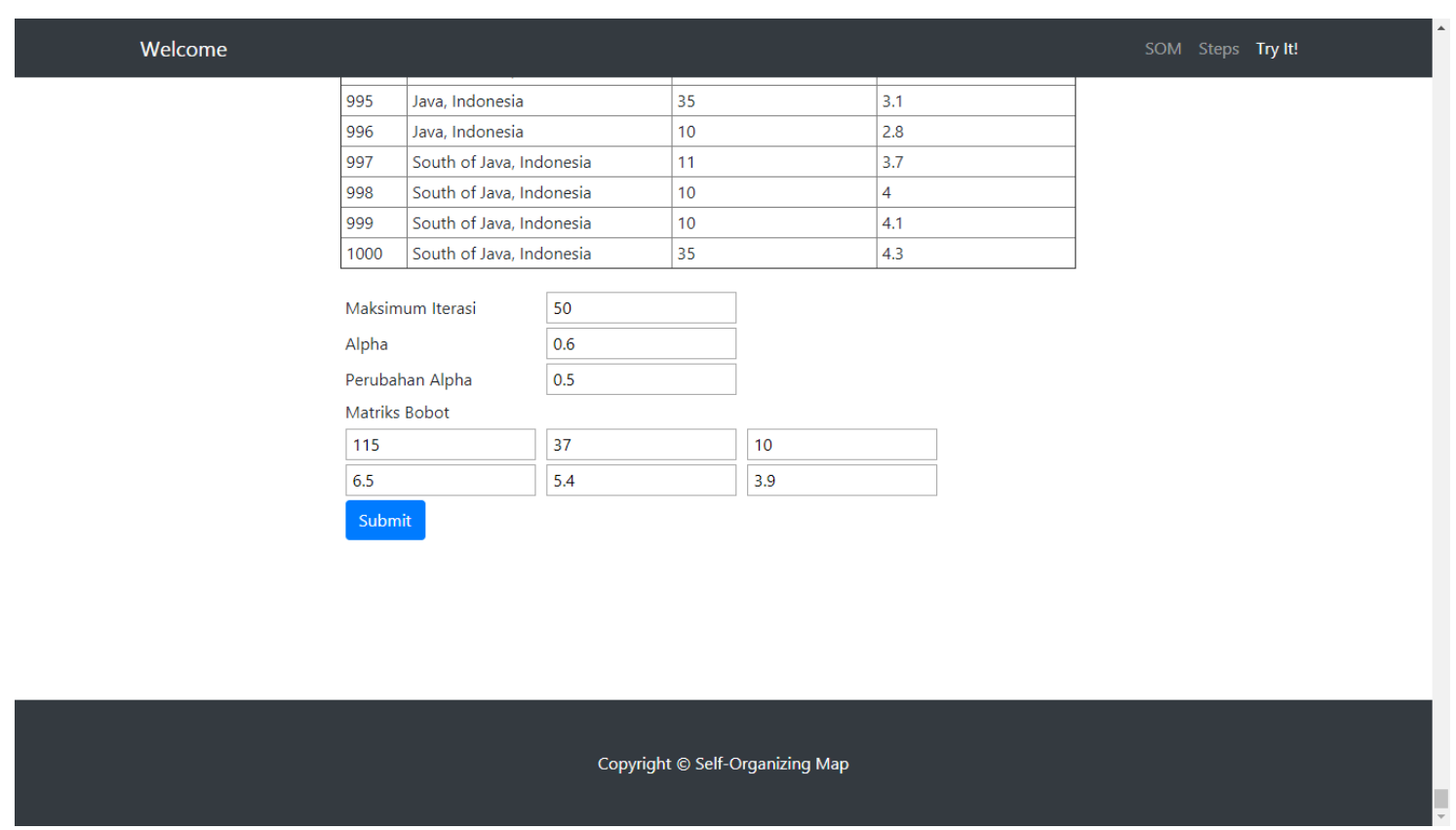

Gambar 4. Tampilan inisialisasi awal

Setelah semua dataset berhasil ter cluster, maka sistem akan menampilkan prosentase pesebaran masing-masing cluster tersebut ke dalam sebuah diagram pie yang terangkum pada Gambar 5. Berdasarkan Gambar 5 diketahui bahwa cluster 1 memiliki jumlah anggota terbanyak yaitu 864 data atau sekitar $86,9 \%$ dengan ditandai dengan warna kuning kunyit, cluster 2 memiliki anggota sebanyak 121 data atau sekitar 11,7\% dengan ditandai dengan warna merah, dan sisanya cluster 3 yang sebanyak 15 data atau sekitar 1,50\% yang diwarnai dengan warna biru 


\section{Welcome}
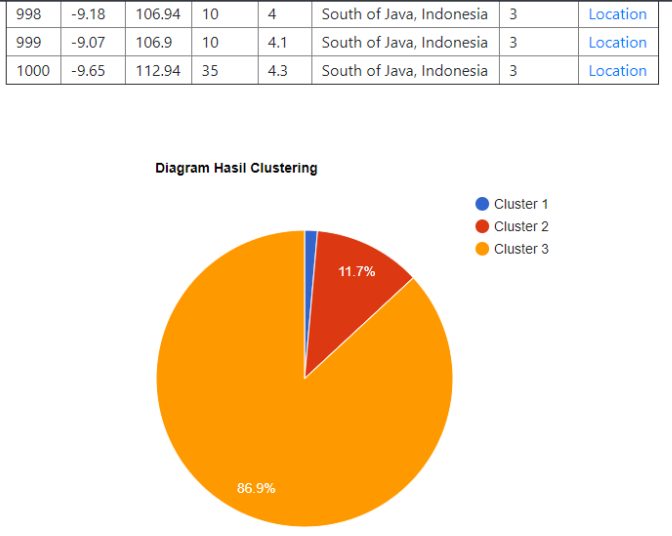

\section{Gambar 5. Tampilan diagram hasil clustering}

Untuk mempermudah mengetahui pesebaran titik pusat gempa yang telah dilakukan, maka dibuatkan juga tampilan visual secara mapping seperti Gambar 6. Nilai 547 merupakan banyaknya gempa yang pernah terjadi pada wilayah tersebut dengan kedalaman dan magnitude yang berbeda.

\section{Welcome}

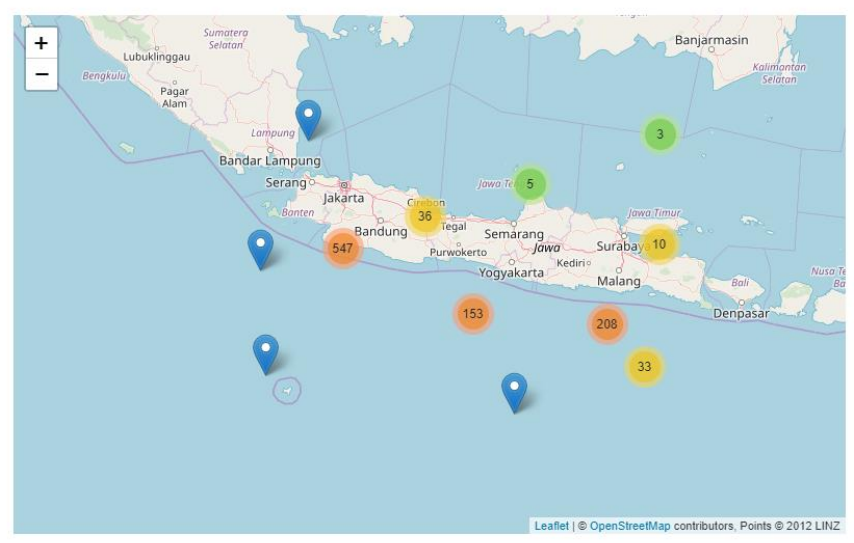

Gambar 6. Tampilan detail kegempaan

Untuk mengetahui akurasi terhadap algoritma SOM, maka dilakukan pengujian melalui metode K-Fold Validation yang akan membagi dataset kedalam 5-fold dan 10-fold melalui 200 data training dan 100 data testing. Pengujian juga dilakukan dengan merubah nilai learning rate $(\alpha)$, dan nilai iterasi. Prosentasi akurasi yang dihasilkan akan dihitung melalui persamaan (5) 


$$
\text { akurasi }=\frac{\text { databenar }}{\text { datatesting }} \times 100 \%
$$

Hasil pengujian 5-fold di berbagai eksperimen learning rate dan akurasi dapat dilihat pada bagan di Gambar 7

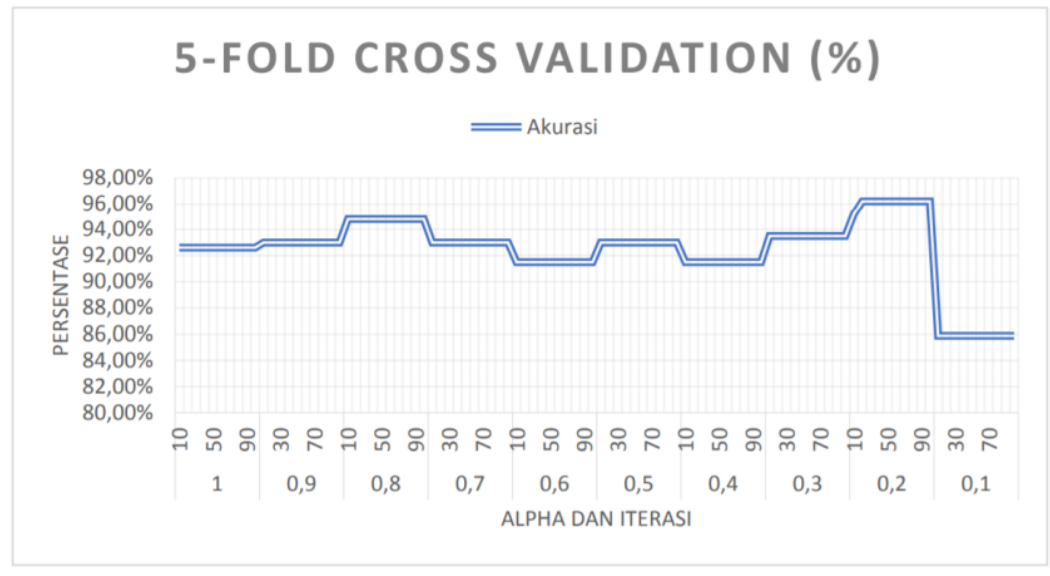

Gambar 7. Akurasi di 5-fold cross validation

Nilai akurasi tertinggi pada 5-fold cross validation adalah 96,20\%. Nilai ini didapat pada eksperimen nilai alpha (learning rate) 0,2 di iterasi 20 sampai dengan iterasi 100. Sebaliknya, nilai akurasi terkecil adalah $85,6 \%$. Nilai ini ada pada eksperimen nilai alpha (learning rate) 0,1 di iterasi 10 sampai dengan iterasi 100. Nilai pengujian di setiap eksperimen nilai alpha dan iterasi dapat dilihat di gambar 8 .

\begin{tabular}{|c|c|c|c|c|c|c|c|c|c|c|c|c|c|c|}
\hline Alpha & Iterasi & Akurasi & Alpha & Iterasi & Akurasi & Alpha & Iterasi & Akurasi & Alpha & Iterasi & Akurasi & Alpha & Iterasi & Akurasi \\
\hline \multirow{10}{*}{1} & 10 & $92,60 \%$ & \multirow{10}{*}{0,9} & 10 & $93 \% \%$ & \multirow{10}{*}{0,8} & 10 & $94,80 \%$ & \multirow{10}{*}{0,7} & \begin{tabular}{|l|}
10 \\
\end{tabular} & $93,00 \%$ & \multirow{10}{*}{0.6} & \begin{tabular}{|l|}
10 \\
\end{tabular} & $91,50 \%$ \\
\hline & 20 & $92,60 \%$ & & 20 & $93 \% \%$ & & 20 & $94,80 \%$ & & 20 & $93,00 \%$ & & 20 & $91,50 \%$ \\
\hline & 30 & $92,60 \%$ & & 30 & $93 \% \%$ & & 30 & $94,80 \%$ & & 30 & $93,00 \%$ & & 30 & $91,50 \%$ \\
\hline & 40 & $92,60 \%$ & & 40 & $93 \% \%$ & & 40 & $94,80 \%$ & & 40 & $93,00 \%$ & & 40 & $91,50 \%$ \\
\hline & 50 & $92,60 \%$ & & 50 & $93 \% \%$ & & 50 & $94,80 \%$ & & 50 & $93,00 \%$ & & 50 & $91,50 \%$ \\
\hline & 60 & $92,60 \%$ & & 60 & $93 \% \%$ & & 60 & $94,80 \%$ & & 60 & $93,00 \%$ & & 60 & $91,50 \%$ \\
\hline & 70 & $92,60 \%$ & & 70 & $93 \% \%$ & & 70 & $94,80 \%$ & & 70 & $93,00 \%$ & & 70 & $91,50 \%$ \\
\hline & 80 & $92,60 \%$ & & 80 & $93 \% \%$ & & 80 & $94,80 \%$ & & 80 & $93,00 \%$ & & 80 & $91,50 \%$ \\
\hline & 90 & $92,60 \%$ & & 90 & $93 \% \%$ & & 90 & $94,80 \%$ & & 90 & $93,00 \%$ & & 90 & $91,50 \%$ \\
\hline & 100 & $92,60 \%$ & & 100 & $93 \% \%$ & & 100 & $94,80 \%$ & & 100 & $93,00 \%$ & & 100 & $91,50 \%$ \\
\hline Alpha & Iterasi & Akurasi & Alpha & Iterasi & Akurasi & Alpha & Iterasi & Akurasi & Alpha & Iterasi & Akurasi & Alpha & Iterasi & Akurasi \\
\hline \multirow{10}{*}{0,5} & 10 & $93,00 \%$ & \multirow{10}{*}{0,4} & 10 & $91,50 \%$ & \multirow{10}{*}{0,3} & 10 & $93,50 \%$ & \multirow{10}{*}{0.2} & 10 & $95,20 \%$ & \multirow{10}{*}{0.1} & 10 & $85,90 \%$ \\
\hline & 20 & $93,00 \%$ & & 20 & $91,50 \%$ & & 20 & $93,50 \%$ & & 20 & $95,20 \%$ & & 20 & $85,90 \%$ \\
\hline & 30 & $93,00 \%$ & & 30 & $91,50 \%$ & & 30 & $93,50 \%$ & & 30 & $95,20 \%$ & & 30 & $85,90 \%$ \\
\hline & 40 & $93,00 \%$ & & 40 & $91,50 \%$ & & 40 & $93,50 \%$ & & 40 & $95,20 \%$ & & 40 & $85,90 \%$ \\
\hline & 50 & $93,00 \%$ & & 50 & $91,50 \%$ & & 50 & $93,50 \%$ & & 50 & $95,20 \%$ & & 50 & $85,90 \%$ \\
\hline & 60 & $93,00 \%$ & & 60 & $91,50 \%$ & & 60 & $93,50 \%$ & & 60 & $95,20 \%$ & & 60 & $85,90 \%$ \\
\hline & 70 & $93,00 \%$ & & 70 & $91,50 \%$ & & 70 & $93,50 \%$ & & 70 & $95,20 \%$ & & 70 & $85,90 \%$ \\
\hline & 80 & $93,00 \%$ & & 80 & $91,50 \%$ & & 80 & $93,50 \%$ & & 80 & $95,20 \%$ & & 80 & $85,90 \%$ \\
\hline & 90 & $93,00 \%$ & & 90 & $91,50 \%$ & & 90 & $93,50 \%$ & & 90 & $95,20 \%$ & & 90 & $85,90 \%$ \\
\hline & 100 & $93,00 \%$ & & 100 & $91,50 \%$ & & 100 & $93,50 \%$ & & 100 & $95,20 \%$ & & 100 & $85,90 \%$ \\
\hline
\end{tabular}

Gambar 8. Nilai akurasi di setiap eksperimen 5-fold

Untuk hasil pengujian 10 -fold di berbagai eksperimen learning rate dan akurasi dapat dilihat pada bagan di gambar 9 . 


\section{0-FOLD CROSS VALIDATION (\%)}

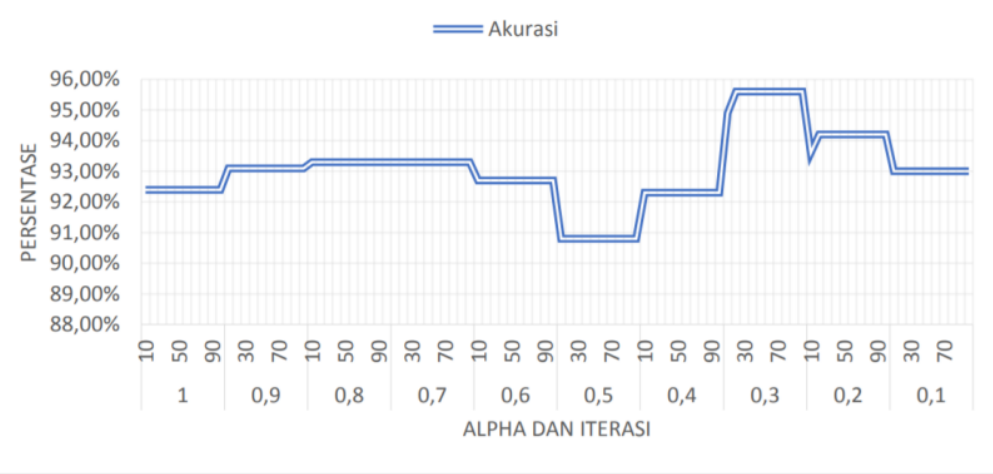

Gambar 9. Akurasi di 10-fold cross validation

Nilai akurasi tertinggi pada 10 -fold cross validation adalah 95,60\%. Nilai ini didapat pada eksperimen nilai alpha (learning rate) 0,3 di iterasi 20 sampai dengan iterasi 100. Sebaliknya, nilai akurasi terkecil adalah 90,8\%. Nilai ini ada pada eksperimen nilai alpha (learning rate) 0,5 di iterasi 10 sampai dengan iterasi 100. Nilai pengujian di setiap eksperimen nilai alpha dan iterasi dapat dilihat di gambar 10.

\begin{tabular}{|c|c|c|c|c|c|c|c|c|c|c|c|c|c|c|}
\hline Alpha & Iterasi & Akurasi & Alpha & Iterasi & Akurasi & Alpha & Iterasi & Akurasi & Alpha & Iterasi & Akurasi & Alpha & Iterasi & Akurasi \\
\hline \multirow{10}{*}{1} & 10 & $92,40 \%$ & \multirow{10}{*}{0,9} & \begin{tabular}{|l|}
10 \\
\end{tabular} & $93,10 \%$ & \multirow{10}{*}{0,8} & 10 & $93,30 \%$ & \multirow{10}{*}{0,7} & $\begin{array}{l}10 \\
\end{array}$ & $93,30 \%$ & \multirow{10}{*}{0.6} & 10 & $92,70 \%$ \\
\hline & 20 & $92,40 \%$ & & 20 & $93,10 \%$ & & 20 & $93,30 \%$ & & 20 & $93,30 \%$ & & 20 & $92,70 \%$ \\
\hline & 30 & $92,40 \%$ & & 30 & $93,10 \%$ & & 30 & $93,30 \%$ & & 30 & $93,30 \%$ & & 30 & $92,70 \%$ \\
\hline & 40 & $92,40 \%$ & & 40 & $93,10 \%$ & & 40 & $93,30 \%$ & & 40 & $93,30 \%$ & & 40 & $92,70 \%$ \\
\hline & 50 & $92,40 \%$ & & 50 & $93,10 \%$ & & 50 & $93,30 \%$ & & 50 & $93,30 \%$ & & 50 & $92,70 \%$ \\
\hline & 60 & $92,40 \%$ & & 60 & $93,10 \%$ & & 60 & $93,30 \%$ & & 60 & $93,30 \%$ & & 60 & $92,70 \%$ \\
\hline & 70 & $92,40 \%$ & & 70 & $93,10 \%$ & & 70 & $93,30 \%$ & & 70 & $93,30 \%$ & & 70 & $92,70 \%$ \\
\hline & 80 & $92,40 \%$ & & 80 & $93,10 \%$ & & 80 & $93,30 \%$ & & 80 & $93,30 \%$ & & 80 & $92,70 \%$ \\
\hline & 90 & $92,40 \%$ & & 90 & $93,10 \%$ & & 90 & $93,30 \%$ & & 90 & $93,30 \%$ & & 90 & $92,70 \%$ \\
\hline & 100 & $92,40 \%$ & & 100 & $93,10 \%$ & & 100 & $93,30 \%$ & & 100 & $93,30 \%$ & & 100 & $92,70 \%$ \\
\hline & & & & & & & & & & & & & & \\
\hline Alpha & Iterasi & Akurasi & Alpha & Iterasi & Akurasi & Alpha & Iterasi & Akurasi & Alpha & Iterasi & Akurasi & Alpha & Iterasi & Akurasi \\
\hline \multirow{10}{*}{0,5} & 10 & $90,80 \%$ & \multirow{10}{*}{0,4} & 10 & $92,30 \%$ & \multirow{10}{*}{0,3} & 10 & $94,90 \%$ & \multirow{10}{*}{0.2} & 10 & $93,60 \%$ & \multirow{10}{*}{0.1} & 10 & $93,00 \%$ \\
\hline & 20 & $90,80 \%$ & & 20 & $92,30 \%$ & & 20 & $95,60 \%$ & & 20 & $94,20 \%$ & & 20 & $93,00 \%$ \\
\hline & 30 & $90,80 \%$ & & 30 & $92,30 \%$ & & 30 & $95,60 \%$ & & 30 & $94,20 \%$ & & 30 & $93,00 \%$ \\
\hline & 40 & $90,80 \%$ & & 40 & $92,30 \%$ & & 40 & $95,60 \%$ & & 40 & $94,20 \%$ & & 40 & $93,00 \%$ \\
\hline & 50 & $90,80 \%$ & & 50 & $92,30 \%$ & & 50 & $95,60 \%$ & & 50 & $94,20 \%$ & & 50 & $93,00 \%$ \\
\hline & 60 & $90,80 \%$ & & 60 & $92,30 \%$ & & 60 & $95,60 \%$ & & 60 & $94,20 \%$ & & 60 & $93,00 \%$ \\
\hline & 70 & $90,80 \%$ & & 70 & $92,30 \%$ & & 70 & $95,60 \%$ & & 70 & $94,20 \%$ & & 70 & $93,00 \%$ \\
\hline & 80 & $90,80 \%$ & & 80 & $92,30 \%$ & & 80 & $95,60 \%$ & & 80 & $94,20 \%$ & & 80 & $93,00 \%$ \\
\hline & 90 & $90,80 \%$ & & 90 & $92,30 \%$ & & 90 & $95,60 \%$ & & 90 & $94,20 \%$ & & 90 & $93,00 \%$ \\
\hline & 100 & $90,80 \%$ & & 100 & $92,30 \%$ & & 100 & $95,60 \%$ & & 100 & $94,20 \%$ & & 100 & $93,00 \%$ \\
\hline
\end{tabular}

Gambar 10. Nilai akurasi di setiap eksperimen 10-fold

\section{KESIMPULAN}

Penelitian yang dilakukan menggunakan algoritma Self-Organizing Map terhadap gempa bumi di Jawa menunjukkan bahwa sangat banyak hasil clustering gempa bumi yang tergolong menimbulkan kerusakan berat sebanyak 864 (86.06\%), kerusakan sedang sebanyak $121(12.10 \%)$, dan kerusakan ringan sebanyak 15 (1.50\%). Pengujian menggunakan 5-Fold dan 10-Fold Cross Validation, didapat akurasi yang tertinggi adalah dengan alpha 0.2 dan 0.3 yaitu sebesar $96.20 \%$ dan $95.6 \%$, dengan akurasi terendah adalah alpha 0.1 sebesar $85.90 \%$. Dapat dilihat juga, bahwa jumlah maksimum iterasi tidak mempengaruhi hasil akhir dari clustering tersebut seperti iterasi 20 yang memiliki hasil sama persis dengan iterasi 100. 


\section{DAFTAR PUSTAKA}

[1] D. P. Utomo and B. Purba, "Penerapan Datamining pada Data Gempa Bumi Terhadap Potensi Tsunami di Indonesia," Pros. Semin. Nas. Ris. Inf. Sci., vol. 1, no. September 2019, p. 846, 2019, doi: 10.30645/senaris.v1i0.91.

[2] R. Prathivi, "Optimasi Algoritme Naive Bayes Untuk Klasifikasi Data Gempa Bumi di Indonesia Berdasarkan Hiposentrum," Telematika, vol. 13, no. 1, pp. 36-43, 2020, doi: 10.35671/telematika.v13i1.928.

[3] H. Sakdiah and Santri, "Kesiapsiagaan Masyarakat Desa Serempah Aceh Tengah Dalam Menghadapi Bencana Gempa Bumi," J. Geuthèë Penelit. Multidisiplin, vol. 02, no. 03, pp. 358-365, 2019, [Online]. Available: http://journal.geutheeinstitute.com/index.php/JG/article/view/70/90.

[4] N. L. G. P. Suwirmayanti, "Penerapan Teknik Clustering Untuk Pengelompokkan Konsentrasi Mahasiswa Dengan Metode Self Organizing Map," J. Ilm. Intech Informatioan Technol. J. UMUS, vol. 2, no. 1, pp. 11-20, 2020, doi: 10.46772/intech.v2i01.182

[5] M. W. Alkhalidi, B. Nadeak, and M. Sayuthi, "Sistem Informasi Geografis Pemetaan Wilayah Penyalahgunaan Narkoba Mengunakan Metode SOM (Self-Organizing Map) Studi Kasus : Kabupaten Aceh Tenggara," Build. Informatics, Technol. Sci., vol. 2, no. 1, pp. 1-9, 2020, [Online]. Available: https://ejurnal.seminarid.com/index.php/bits/article/view/132/184.

[6] F. Tempola, M. Muhammad, and A. Khairan, "Perbandingan Klasifikasi Antara Knn Dan Naive Bayes Pada Penentuan Status Gunung Berapi Dengan K-Fold Cross Validation Comparison of Classification Between Knn and Naive Bayes At the Determination of the Volcanic Status With K-Fold Cross," J. Teknol. Inf. dan Ilmu Komput., vol. 5, no. 5, pp. 577-584, 2018, doi: 10.25126/jtiik20185983.

[7] N. N. Halim and E. Widodo, "Clustering dampak gempa bumi di indonesia menggunakan kohonen self organizing maps," Pros. SI MaNIS (Seminar Nas. Integr. Mat. dan Nilai Islam., 2017.

[8] I. H. Rifa, H. Pratiwi, and Respatiwulan, "Implementasi algoritma clara untuk data gempa bumi di indonesia," Semin. Nas. Penelit. Pendidik. Mat., pp. 161-166, 2019, [Online]. Available: http://jurnal.umt.ac.id/index.php/cpu/article/view/1694/1087.

[9] A. Hepita and R. F. Hakim, "Pengelompokan Dampak Gempa Bumi Dari Segi Kerusakan Fasilitas Pada Provinsi Yang Berpotensi Gempa Di Indonesia Menggunakan K-means-Clustering," Pros. Semin. Nas. Mat. dan Pendidik. Mat. UMS, 2015.

[10] M. S. Yana, L. Setiawan, E. M. Ulfa, and A. Rusyana, "Penerapan Metode K-Means dalam Pengelompokan Wilayah Menurut Intensitas Kejadian Bencana Alam di Indonesia Tahun 2013-2018," J. Data Anal., 2018, doi: 10.24815/jda.v1i2.12584.

[11] S. N. Kapita and S. Do Abdullah, "Pengelompokkan Data Mutu Sekolah Menggunakan Jaringan Syaraf Tiruan Kohonen-SOM," JIKO (Jurnal Inform. dan Komputer), vol. 3, no. 1, pp. 56-61, 2020, doi: http://dx.doi.org/10.33387/jiko.v3i1.1737.

[12] E. Turban and R. Sharda, Business Intelligence and Analytics: 10th Edition. Harlow (UK): Pearson Education, 2018.

[13] Suyanto, Data Mining Untuk Klasifikasi dan Klasterisasi Data. Bandung: Informatika Bandung, 2017.

[14] A. Premana, R. M. H. Bhakti, and D. Prayogi, "Segmentasi K-Means Clustering Pada Citra Menggunakan Ekstraksi Fitur Warna dan Tekstur," J. Ilm. Intech Informatioan Technol. J. UMUS, vol. 2, no. 1, pp. 89-97, 2020, doi: 10.46772/intech.v2i01.190

[15] D. A. Nasution, H. H. Khotimah, and N. Chamidah, "Perbandingan Normalisasi Data untuk Klasifikasi Wine Menggunakan Algoritma K-NN," CESSM - J. Comput. Eng. Syst. Sci., vol. 4, no. 1, pp. 78-82, 2019, doi: 10.24114/cess.v4i1.11458.

[16] H. P. Lestari, S. Wahyuningsih, and D. T. Amijaya, "Prediksi Klasifikasi Royalti 
Batubara Menggunakan Algoritma Fuzzy K-Nearest Neighbor ( Studi Kasus : CV . Fazar Utama)," J. Eksponensial, vol. 10, no. 1, pp. 81-88, 2019, [Online]. Available: http://jurnal.fmipa.unmul.ac.id/index.php/exponensial/article/view/395/180.

[17] I. A. Nikmatun and I. Waspada, "Implementasi Data Mining untuk Klasifikasi Masa Studi Mahasiswa Menggunakan Algoritma K-Nearest Neighbor,” J. SIMETRIS, vol. 10, no. 2, pp. 421-432, 2019, doi: https://doi.org/10.24176/simet.v10i2.2882. 